\title{
YOUTH EXPRESSIONS OF RELIGIOSITY THROUGH DIALOGUE IN INDONESIA
}

\author{
Fattimah Husein \\ State Islamic University Sunan Kalijaga Yogyakarta \\ <fatimahhusein@yahoo.com>
}

\begin{abstract}
This paper observes youth expressions of religiosity through inter-religious dialogue in Indonesia. It focuses on how Indonesian youth examine their interpretations of their own religions and their efforts at building interfaith and peace networks through various programs. It then explores these initiatives using the theory of the seven moments of dialogue proposed by the Indonesian theologian J.B. Banawiratma. By examining these initiatives, the paper offers some grounded observations on the positive contributions that Indonesian youth has made amidst the changing religious proclivities of their peers toward a more conservative turn.
\end{abstract}

\section{Introduction}

Youth is an interesting and challenging phase in life, full of opportunities for new experiences and new relationships. Over the last two decades, while the rapid growth of the internet and information technology has instilled in young people a new kind of global awareness, it has also engendered in them a greater anxiousness about their own futures. This, to some extent, has contributed to young people pursuing contradictory roles; on the one hand, they played a significant and positive role in processes of social, political, and economic change, and, on the other, they also participated in violent actions. Indonesian youth have also engaged in these contradictory roles. On the one side, young people, especially university students, organized peaceful rallies and protests that contributed to the downfall of the authoritarian regime of President Soeharto in 1998. However, one the other side, we also witnessed the rise of youth participation in violence against 
religious minority groups. ${ }^{1}$

In part to address the problem of rising youth participation in violence against religious minority groups, this paper is to promote youth expressions of religiosity through inter-religious dialogue in Indonesia by examining their religious interpretations of their own religions and their efforts at building interfaith and peace networks through various programs and followup activities. Following an overview of efforts at inter-religious dialogue and the question of the place for youth in it, I will discuss five programs and initiatives in which I have been involved to some extent: 1) Youth Interfaith Forum on Sexuality (YIFoS), 2) Youth Interfaith Gathering, Concert, and Advocacy for Pluralism, 3) Young Interfaith Peacemaker Community Indonesia, 4) Interfaith Youth Pilgrimage, 5) Indonesian participation in the Vienna International Christian-

1 Eric Hiariej has identified that at least 15 bombings during the last two decades in Indonesia, most of them involving youth as actors. These include:Phillippine Embassy bombing and thirty-eight church bombings on Christmas Eve in Riau, Jakarta, Java West, Central Java, East Java, West Nusa Tenggara (2000); HKBP and Santa Ana church bombings, Atrium Mall, Petra Church, all are in Jakarta (2001); U.S. Embassy Warehouse, Bali bombing 1, Consulate House of U.S. Government in Bali, Consulate House of Philippine Government in North Sulawesi (2002); United Nations building in Jakarta, Soekarno-Hatta International Airport, Parliament House parking lot in Jakarta, JW Marriot Hotel in Jakarta (2003); Australian Embassy building (2004), and the second Bali bombing (2005). Eric Hiariej, "Aksi dan Identitas Kolektif Gerakan Islam Radikal di Indonesia" in Jurnal IImu Sosial dan IImu Politik, Vol. 14, No. 2 (2010): 131-168. See also, Noorhaidi Hasan, "Violent Activism, Islamist Ideology, and the Conquest of Public Space among Youth in Indonesia," in Kathryn Robinson, ed., Youth Identities and Social Transformations in Modern Indonesia (Leiden: Brill, 2016), pp. 200-213.
Islamic Summer University (VICISU). The last part of this paper will examine these initiatives using the theory of the seven moments of dialogue proposed by the Indonesian theologian J.B. Banawiratma. ${ }^{2}$

\section{Background: Inter-religious Dia- logue and the Role of Youth}

Inter-religious dialogue has become a global issue that has received much attention from various sectors of global society, especially from academics and theologians. This issue came to the fore in the early 1960s at a time of more intensive contact between religious communities. The Second Vatican Council called Catholics to keep an open attitude towards interactions with people of other beliefs and this was followed by other initiatives from Protestant $^{3}$ and Islamic organizations. ${ }^{4}$ Inter-religious dialogue efforts at the international level grew in the 1970s, beginning with the World Conference on Religion and Peace (WCRP) held in Kyoto, Japan, in 1970. At that conference a big leap forward in terms of paradigms for dialogue was proposed

2 J.B. Banawiratma, Zainal Abidin Bagir, et.al., Dialog antarumat Beragama: Gagasan dan Praktik di Indonesia (Bandung: Mizan, 2010).

3 Anglican churches started to include discussions on inter-religious dialogue at Lambeth Conference Resolution in 1968. For a detailed account on Anglican churches efforts for inter-religious dialogue, see: www.anglican-communion.org and www. lambethconference.org.

4 Within the Muslim circles, some early initiatives for inter-religious dialogue were encouraged by the Secretary General of the Mu'tamar al-'Alam al-Islami (World Muslim Congress) in 1969. See: www.wmc.org. sa and themwl.org. 
- dialogue could no longer deal only with theories and theologies but also must include the level of action. Issues of interest for WCRP include conflict transformation, children's rights, peace, and human rights. ${ }^{5}$ One of the more recent efforts in inter-religious dialogue at the international level was the visit of Saudi King Abdullah bin Abdul Aziz to the Vatican in 2007, the foundation of King Abdullah bin Abdul Aziz International Center for Interreligious and Intercultural Dialogue in Vienna in 2011, and the signing of a document "Human Fraternity for World Peace and Living Together" by Pope Francis and the Grand Imam of al-Azhar on 4 February 2019. These have brought new hopes for world peace and better communication among religious believers.

The primary actors in efforts for inter-religious dialogue in the Indonesian context come from three sectors, namely; government, civil society organizations, and academia. Though I do not have the space here to provide a full account of the history of inter-religious dialogue in Indonesia, I will briefly summarize the efforts of these three groups to put my discussion into context. ${ }^{6}$ Initiatives for dialogue in Indonesia began as early as 1967 , in

5 See: http://www.religionsforpeace.org/visionhistory/history, and http://wcc-coe.org/wcc/what/ interreligious/cd48-10.html.

6 Among other research on this topic include: J.B. Banawiratma, Zainal Abidin Bagir, et.al., Dialog antarumat Beragama: Gagasan dan Praktik di Indonesia. the wake of the 1965 coup that brought Soeharto to power, as a response to local conflicts involving religious communities, and institutional support for inter-religious dialogue began with the late Mukti Ali, then Indonesian Minister of Religious Affairs, in 1969 . $^{7}$ After 1965, the situation of religious life of Indonesians was quite difficult. Soeharto's New Order government (in power from 1966-1998) introduced a strict policy under which every citizen was required to embrace one of five religions recognized by the state, namely: Islam, Protestant Christianity, Catholicism, Buddhism, or Hinduism. Hundreds of local beliefs were, and still are, neglected and/or perceived as non-existent. The policy gave rise to new waves of converts to the five religions, in Java mostly to Christianity. There has been some research into the reasons behind the significant increase in conversions to Christianity following the 1965 coup, and suffice to say here that the circumstances then resulted in rising prejudice and tension among religious groups, especially between Muslims and Christians. ${ }^{8}$

Responding to this situation, the government initiated the Interreligious Council in Jakarta on 30 November 1967, under the leadership

\footnotetext{
7 See, Mukti Ali, "Dialogue between Muslims and Christians in Indonesia and Its Problems," paper presented at World Council of Churches, Lebanon, 1970.

8 See, among others, B.J. Boland, The Struggle of Islam in Modern Indonesia (The Hague: Martinus Nijhoff, 1982), pp. 230-233.
} 
of the Minister of Religious Affair and attended by representatives of Muslim and Christian groups. The government asked both groups to not target people who already embraced a religion. This was not accepted by many Christians who perceived missionary work as part of God's command. Even though this first effort at religious dialogue was not successful, the government through the Ministry of Religious Affairs (MoRA) continued to conduct some other programs intended to maintain harmonious relations between religious communities. ${ }^{9}$

Another attempt from the government was by the Ministry of Foreign Affairs (MFA) following 9/11. Through its Directorate of Public Diplomacy, it has held dialogues that show new motivations and a new urgency to build understanding between communities at the international as well as national levels. Programs conducted through this effort by the MFA include bilateral interfaith and inter-cultural dialogue symposia with some European countries as well as the USA, joint research and publications, and student

9 Inter-religious dialogue initiated by the government often employed a top-down approach in which harmony and peaceful conditions among religious believers were perceived as the responsibility of religious leaders and government. Sunardi called this model of dialogue unproductive since success was defined as the absence of conflict. See St. Sunardi, "The Dead End of Religious Dialogue in Indonesia," Interface, No.4 (May 2001): 56. A more recent efforts by the government include the establishment of Forum Kerukunan Umat Beragama (Forum for Interreligious Harmony) in 2006. This forum was created as a medium of communication between government, religious leaders and community to create harmony. and professor exchanges. ${ }^{10}$ The efforts are not only limited to academic circles but also include some advocacies for developing and Muslim countries that are struggling with their domestic problems.

It was primarily against the background of the New Order that some civil society organizations (CSO) created their own versions of interfaith and inter-religious dialogue. These organizations, such as Interfidei (Institute for Interfaith Dialogue in Indonesia) established in December 1991, clearly chose the word "faith" over "religion" which they perceived as somehow co-opted by the New Order regime. Interfidei emerged as a critique of the dialogue efforts by the government as top-down and only involving religious elites. It argued that the problem of inter-religious relations in Indonesia is not one of religious teachings, but rather of social injustice. Interfidei and some other CSOs have been very active in promoting and fostering dialogue among religious believers around the country through various programs and publications. ${ }^{11}$

At the academic level, a new trend

10 One joint publication was Stefan Hammer and Fatimah Husein, eds., Religious Pluralism and Religious Freedom: Religions, Society and the State in Dialogue, which was written by Austrians and Indonesians, published in Indonesia by CRCS UGM (2013) and funded by the Department of Legal Philosophy, Law of Religions and Culture of the University of Vienna, Austria.

11 Th. Sumartana, "Sejarah Singkat, Visi dan Misi Institut DIAN/Interfidei, Interfidei Newsletter, Special Edition 2001, 5. For some other initiatives by CSOs on inter-religious dialogue, see Banawiratma and Bagir, pp. 131-186. 
emerged in late 1990s in the form of the establishment of religious studies programs which are distinguished from theological programs. The establishment of such programs can be also traced back to Mukti Ali, who was the Chairman of the Department of Comparative Religion at the Institute of Islamic Studies (IAIN) Yogyakarta in the early 1960s before he became Minister of Religious Affairs. Even though at the beginning these programs placed a heavy emphasis on Muslims' perspectives on the "religious other," the conversion of some IAINs into State Islamic Universities (UINs) provided more opportunities to develop a more historical study of religions. In the 1990s, private universities such Satya Wacana Christian University (UKSW), Duta Wacana Christian University (UKDW), and Sanata Dharma Catholic University also developed religious studies alongside their theology programs. New study programs, courses on dialogue, as well as academic centers on dialogue were also developed, for example; the establishment of Center for Religious and Cross-cultural Studies (CRCS) of Gadjah Mada University in 2000, and Indonesian Consortium for Religious Studies (ICRS) which is a consortium of State Islamic University Sunan Kalijaga, Gadjah Mada University, and Duta Wacana Christian University in 2006. In the new study programs, dialogue takes place not only as a matter of curriculum but also within the religiously diverse student body and faculty. ${ }^{12}$

As the above account shows, youth have not been a primary focus of inter-religious dialogue in Indonesia even though there is a strong awareness of the importance of involving youth in inter-religious dialogue efforts and activities. In fact, Indonesian youth have already taken the initiative to not only ask to be involved in interreligious dialogue programs but also to become key actors in such programs. Yet, there has been little attention paid to examining youth participation and contributions to interfaith dialogue. In my view, instead of leaving youth participation in inter-religious dialogue unrecognized and unappreciated, their participation should be encouraged and various steps should be taken to assist them.

\section{Youth Interfaith Forum on Sexuality (YIFoS)}

After I joined the Fulbrightsponsored Interfaith Community Action Program (ICAP) in SeptemberDecember 2008 that enabled me to travel to several states in the United States and learned more deeply about multicultural religious life there, in 2010, I proposed an interfaith action program initiative for young Indonesians under the theme "Interfatih Youth Community Action in Indonesia: Working Together with People Living

12 Banawiratma and Bagir, pp. 187-230. 
with HIV\&AIDS and LGBT" to the Institute of International Education (IIE) in response to the challenge from the ICAP to expand the impact of the interfaith action program in my own country. The aim of this program was to bring youth from various religions and other identity backgrounds to think about some common issues in order to create an interfaith strategy and action, particularly in regard to HIV\&AIDS and the issues facing LGBT people in Indonesia.

Twenty university students participated in this ten-day long program. The backgrounds of the participants were quite an interesting mix. Their fields of study ranged from mathematics to the arts and they came from big cities like Jakarta and Bandung as well as small villages in remote areas of Central Java including Wonosobo and Jepara. The recruitment process required applicants to have some links to community or religious organizations. Their diverse religious and faith backgrounds not only enriched the multicultural atmosphere of the program, but also greatly contributed to the discussions of existing perceptions (and prejudices) about HIV\&AIDS and LGBT Indonesians.

The program was divided into three main activities:

1. Lectures: participants were first introduced to conduct a selfanalysis and to understand the concepts of sexuality and gender.
They also learned about lesbian, gay, bisexual and transgender identities in terms of definitions, history, the issue of human rights, biological and cultural connections, and movements. The biological perspective on sexuality was most interesting for the participants as it enriched the participants' knowledge on LGBT issues. The participants also watched a movie where they saw a portrait of gay people in their daily lives, especially in their struggles for rights. The movie motivated participants to discuss about the rights of LGBT people and the need to advocate for their rights. In addition, they also learned about HIV\&AIDS. The discussion included the definitions, treatment, types of viruses and their survival within the body. One message that was underlined was the importance of co-operation between people of different faiths by emphasizing the similarities within religious doctrines and not the differences. The phenomenon of HIV\&AIDS provided the foundation of people from different faith traditions to work together. The central problem here lies in recognizing that religions and religious teachings can be changed, even if it takes a long time. The students concluded that it is important to go back to the very central issue within religion, which is "humanity." 
2. "Live-in": After the participants learned enough knowledge about LGBT issues and HIV\&AIDS, they were placed in one of four communities to participate in its life for three full days: an LGBT community called People Like Us "Satu Hati" (One Heart) where they learned to understand problems faced by the community, Kebaya (Keluarga Besar Waria Yogyakarta) a community center for the transgender (waria) community in Yogyakarta, the Pesantren Waria "Senin Kemis" (Monday Thursday) which is an Islamic school and community center for transgendered people to learn Islamic ways, and JORHI (Jaringan Orang Terinfeksi HIV \&AIDS) which is a network of people living with HIV and AIDS.

3. Reflection: On the tenth and final day of the program, the participants reflected on what they learned from the lectures and "live-in" experiences.

Upon the completion of this program, some participants stayed in close contacts and established "Forum Aksi Pemuda Lintas Iman" (Youth Interfaith Action Forum), which was later changed into YIFoS (Youth Interfaith Forum on Sexuality) aimed at building a discussion, advocacy and action related to faith and sexuality. They try to deconstruct taboos in relations to sexuality and take it further by linking the discussion on gender and sexuality from religious perspectives. These members, who are young people of various identity backgrounds including faith and religion, engage in the discussion on religious norms in relation to sexuality and try to move beyond the taboo and make sense of the existence of LGBT people.

This is for sure not an easy task given the context of Indonesia where the majority are Muslims and look at the "non-normative" sexual orientations, such as LGBT, as taboo. ${ }^{13}$ Through its tagline "Building Peace within Diverse Faith and Sexual Identities" YIFoS tries to negotiate, advocate, and resist discriminations based on sexual orientations, and seeks alternative religious interpretations on sexual orientations. They argued that our body was imprisoned by various religious and social norms so that we are afraid to take any decision for our own body. Since 2012 this organization has spent more than USD $\$ 15,000$ in conducting programs which aim at building multidialogue identities related to diversities of faith and sexual identities. This group is quite active in social media until

13 Among research on this topic include: Rinaldi Ridwan and Joyce Wu, "Being Young and LGBT, What could be Worse? Analysis of Youth LGBT Activism in Indonesia: Challenges and Ways Forward," Gender and Development, 26: 1 (2018): 121-138, and Suvianita Khanis, "Human Rights and the LGBTI Movement in Indonesia," Asian Journal of Women's Studies, 19: 1 (2013): 127-138. A more recent debate involving the issue of non-normative sexual orientations emerged when the government drafted a Bill on Elimination of Sexual Violence (Penghapusan Kekerasan Sexual), which was perceived by some Muslims as legalizing adultery and the existence of LGBT people. 
now. ${ }^{14}$

\section{Youth Interfaith Gathering, Concert, and Advocacy for Pluralism}

The Youth Interfaith Gathering and Concert for Harmony were part of the World Interfaith Harmony Week (WIHW), which was proposed by King Abdullah II of Jordan at the United Nation General Assembly in September 2010 and then adopted by the UN. Thereafter, the first week of February each year is observed internationally as a time to recognize and reflect on teachings of tolerance, peace and respect to others. This occasion also provides opportunities for interfaith groups to become aware of each other and strengthen the movement. WIHW cannot be separated from the pioneering work of the Common Word initiative which was started in 2007 and calls for Muslim and Christian leaders to engage in a dialogue based on two common fundamental religious commandments they share without compromising any of their respective religious tenets: "Love of God, and Love of the Neighbour."15

In extending the spirit of WIHW, the Center for Religious and CrossCultural Studies (CRCS), Gadjah Mada

14 Report on "Interfaith Youth Training: Remaja HIV \& AIDS dan LGBT; Merancang Strategi dan Aksi Lintas Iman," Yogyakarta, 1-10 February 2010, unpublished. See also its Instagram account @yifos_indonesia. YIFoS is also quite active in campaigning for the issuance of the Law on Elimination of Sexual Violence mentioned above.

15 For more information of WIHW see wwW. worldinterfaithharmonyweek.com and www.un.org/ en/events/interfaithharmonyweek
University and Indonesian Consortium for Religious Studies, Yogyakarta created programs focusing on youth. The decision to focus on youth was because most existing inter-religious initiatives were focused on religious leaders. The two main programs that were held were Youth Interfaith Gathering focusing on "Youth, Religion and Disaster," and a music performance entitled "Youth, Peace and Harmony."

The gathering on "Youth, Religion and Disaster" took place on 12 February 2011 involving 36 students from five universities in Yogyakarta_Gadjah Mada University (a public and religiously neutral university), Sanata Dharma University (a Catholic university), State Islamic University "Sunan Kalijaga", Duta Wacana Christian University, and Nazarene Theology Institute - and from various religious backgrounds: Islam, Protestant, Catholic, Buddhism and Hinduism. The gathering was aimed at opening a space among youths from different backgrounds of religion, discipline, and cultural tradition to communicate with each other and improve inter-religious cooperation among them.

The discussion centered on the participants' ideas and experiences on possible relationships between religion and disaster. It emphasized the need of youth to uphold the virtue of humanity in helping people struck by disasters without considering the religious 
backgrounds of the victims. They were also reminded that social action could provide a very good platform for uniting people of various religious backgrounds. ${ }^{16}$ During this program the participants also had an opportunity to visit areas affected by the $2010 \mathrm{Mt}$. Merapi eruption disaster at Bronggang Hamlet, Cangkringan, interact directly with survivors, learn more about people's perception in facing disasters, as well as reflecting on disaster in terms of their own faith's teachings and values. ${ }^{17}$

The Concert for Harmony "Youth, Peace and Harmony" was held two weeks later at the Koesnadi Hardjosoemantri Cultural Center, Yogyakarta and featured performances by artists and musicians from Yogyakarta and Jakarta. It aimed at promoting messages of peace and the spirit of inter-religious dialogue, which is the soul of WIHW. CRCS Director Zainal Abidin Bagir stated that "We hope the messages of harmony and spirit of peace of this event are not only transferred to the audience, but also to the musicians performing, thus in the future the works they create will be filled with the spirit of this event."18

Both events mentioned above

$16 \mathrm{http}: / / u g m . a c . i d / e n / n e w s / 6058$-interfaith.joint. humanitarian.activities.should.be.encouraged 17 http://ugm.ac.id/en/news/6182-interfaith. students.in.yogyakarta.open.religious.and.disaster. dialogue

$18 \mathrm{http}: / /$ ugm.ac.id/en/news/6228-crcs.holds.concert. of.harmony.youth.religion.and.peace, see also http:// www.theharmonyintl.com/44-uncategorised/85world-interfaith-harmony-week-events.html. were clearly targeted at and conducted by youth. By choosing the theme of disasters, which have frequently hit Indonesia in the last few years and music as a medium, which is very close to youth, we hoped to develop communication and networks among youth of different religious backgrounds. These kinds of events provide opportunities for youth to reflect on their various religious tenets related to the "religious other" and to break down misunderstandings and suspicions among religious believers. Unfortunately this kind of program is no longer offered by CRCS and ICRS due to some other programs they are handling at the moment.

In addition to those two events, CRCS's concern for youth and pluralism was also manifested in its collaboration with Hivos and Kosmopolis in the "Pluralism Knowledge Program" (PKP) that has been in operation since 2008. The program is an academicpractitioner collaboration, which works towards developing civil societybased strategies to increase spaces for pluralism in practice. Here pluralism is defined as "accepting diversity and engaging with the other. Pluralism is more than tolerance, it is active seeking of understanding across lines of difference." One of the focuses of PKP is working with youth because they have often been forgotten in the agenda of promoting pluralism. In fact, involving youth in this agenda is very 
important because they have become the target of ideological infiltration by the extremist and fundamentalist groups. ${ }^{19}$

Numerous programs, activities, and publications have been conducted through PKP. Publications related to youth include The School as Public Space (Ruang Publik Sekolah), Contesting Morality: Youth Piety and Pluralism in Indonesia, and Reflection on Advocacy. The last publication presents reflections by activists addressing the most pressing problems associated with the management of diversity in Indonesia in relation to youth, marginalized groups, and public policy and strategies in facing these problems. Issues discussed include: "youth, new media, and pluralism," "art and tolerance to diversity in Indonesia," "involving youth in the campaigns for feminism and democracy," "sexuality and gender diversity," and "developing inter-faith relations in the local context." 20

\section{Young Interfaith Peacemaker Community Indonesia}

Also concerned that inter-religious dialogue or inter-religious gathering in general is often facilitated by the government and attended by religious elites, two ICRS students decided to focus their time and energy in targeting students as agents of peacemaking.

19 See: http://crcs.ugm.ac.id/pluralism/profile. 20 See: http://crcs.ugm.ac.id/pluralism/pluralismadvocacy/information/5/ESSAYS-REFLECTING-ONADVOCACY.html.
They established Young Interfaith Peacemaker Community Indonesia (earlier called Young Peacemaker Community) in 2012 and conducted their first Young Peacemaker Training in July 2012 in Yogyakarta followed by their Student Interfaith Peace Camp in November 2012. They have been reshaping the training into regular meetings on interfaith issues and inclusive values in their respective scriptures, as well as holding camps. Young Interfaith Peacemaker Community Indonesia (YIPC Indonesia) has the motto "Building a Peace Generation through Young Peacemakers." ${ }^{21}$

In the first half of 2013, YIPC Indonesia held three Interfaith Peace Camps for students in Sumatera, Surabaya, and in Yogyakarta. Since then YIPC Indonesia has established branches in those three areas and has held regular programs related to interfaith dialogue. Along with the increased number of branches, the activities of YIPC Indonesia are more diverse. In July 2013 they commemorated their first anniversary by organizing a Young Peacemaker National Interfaith Conference, which was attended by nearly fifty people from various cities. The conference was held in Magelang, Central Java, with the theme "Loving God - Loving

21 For information on YIPC Indonesia please see: http://younginterfaithpeacemaker.org/. See also, http://worldinterfaithharmonyweek.com/eventreport-2/?report=972. 
Others, Let's Do Something About It" with the discussion based on the document "A Common Word Between You and Us." In August 2014, YIPC Indonesia held its national conference in Yogyakarta entitled "Experiencing Interfaith Dialogue Holistically to Build a Peace Generation." Lasting six days, the conference was attended by 42 students and leaders and facilitated by nine experts as speakers. Participants were from across Indonesia: Banda Aceh, Medan, Jakarta, Bandung, Semarang, Yogyakarta, Solo, Surabaya, Madura, Samarinda, Makassar, and Ambon. There were 21 male and 21 female participants consisting of 19 Muslims and 23 Christians. Other than sessions in a seminar style, there were small group discussions and sharing to make the interaction more personally intense. On the fifth and sixth days, the programs were conducted outdoors with an interfaith tour and peace campaigns. In addition to those activities, YIPC Indonesia also conducted another national student Interfaith Peace Camp later the same month for five days in Yogyakarta. There were 31 students, both Muslims and Christians, and 15 facilitators, plus two committees from ICRS. Participants came from across Indonesia: Medan, Semarang, Yogyakarta, Surabaya, Aceh, Malang, Ambon, Kalimantan, Makassar, and Madura.

YIPC Indonesia continues to contribute as an agent of peacemaking not only in Indonesia and among Indonesians, but it has also reached out to neighboring countries, such as Malaysia and Singapore. In February 2015, as part of their participation of the World Interfaith Harmony Week, 22 Indonesian students went to Malaysia and Singapore to share about religious harmony in Indonesia and to inspire youth in those countries to form their own student interfaith communities as agents of peace. Three-day Student Interfaith Peace Camps were held in eight cities around Indonesia in May 2015, and the Young Interfaith Peacemaker International Camp was held on 24-30 June 2015 in Yogyakarta.

Today YIPC Indonesia has developed its regional branches and each has their own programs and activities. The former participants of YIPC programs initiate many of these branches. The peace camp that I joined in Bandung was held in November 2018 and was also run by a former YIPC member. It was participated by many students around the area, especially students from the State Islamic University Sunan Gunung Jati Bandung. The participants freely discussed their own belief and its relations to their views of the "religious other." In addition to class discussions and activities, the participants joined a peace campaign through games at Alunalun Bandung to minimize stereotypes among Muslims and Christians.

We have witnessed the magnitude 
of the contribution of the Young Peacemaker Interfaith Community (YIPC) Indonesia. Since its establishment in 2012, YIPC Indonesia has undertaken efforts in peace education among students from different cities and campuses across Indonesia as well as for students from neighboring countries. More than 500 student leaders, both Muslims and Christians, have studied peace values and been trained to be peacemakers.

\section{Interfaith Youth Pilgrimage}

Interfaith Youth Pilgrimage is one of the winners of a grant from the Alumni Engagement Innovation Fund 2013 funded by the American Embassy. Alumni of any program sponsored and organized by the US Department of State are eligible to apply, and a proposal from ICRS Yogyakarta for an "Interfaith Youth Pilgrimage" program won the competition in 2013. The program brought 23 youth from various regions in Indonesia where there has been conflict involving religious identities, including Aceh, Poso, Sampang, Ambon, Kupang, Papua and Yogyakarta, together to experience a ten-day pilgrimage to various sacred spaces. This was meant to provide knowledge related to social and religious conflicts in Indonesia, as well as to strengthen inter-religious peace networks among the participants. Using a multi-religious pilgrimage approach, these young people experienced the sacred spaces of 'the other.'22

The program included lectures and discussions on Conflict Resolution and the History of Religion, visits to religious sacred places such as the Christian Church of Java in Dagen, Solo, Central Java and a Hindu Temple in Central Java, and interfaith-NGOs. There was also an opportunity for Christian students to stay at an Islamic Boarding School and for Muslims to stay in the homes of Christian families. Several participants also spent the night with religious minority groups such as Sapta Dharma and Ahmadiyah communities. Participants shared their stories in e-journals and created online photo stories in blogs and social media, and they wrote essays about the minority groups. ${ }^{23}$

It is interesting to note that this activity produced a peace petition and a draft book entitled God is Omnipotent. The petition entitled "A Petition for Peace in Indonesia" was signed by 28 Indonesian youth coming from diverse ethnic, religious, and geographical backgrounds. It emphasized the important roles of the Indonesian state and civil society in creating peace for all Indonesians, regardless of their religious backgrounds. It also encouraged youth to become agents for peace. The draft book consists of 27 essays by the

22 See: http://icrs.ugm.ac.id/video-gallery/detail/21/ interfaith-youth-pilgrimage.html.

23 See, for example, lifestyle.kompasiana.com/ catatan/2013/11/14/catatan-perjalanan-interfaithyouth-pilgrimage-1-609349.html. 
participants related to five themes: Humanity, God, Sanctuary, Dialogue, and Peace.

What is important from the above brief description on IYP is that the participants were encouraged to engage in social media and to learn how to spread positive sentiments and values to the public through the social and other media. ${ }^{24}$ This is a very significant effort as youth often use social media and therefore spreading this peace campaign through these media by and for youth would most probably attract their interest.

\section{Indonesian Participation at the VICISU}

One of the international organizations which concerns youth and has been working with youth in promoting and advocating for interreligious dialogue is the Vienna International Christian-Islamic Summer University (VICISU), held for three weeks every other year at Benedictine Monastery in Altenburg, near Vienna, Austria. It evolved out of an inter-religious and interdisciplinary academic forum called Vienna International Christian-Islamic Round Table (VICIRoTa) initiated by Father Andreas Bsteh at the Institute for Theology of Religions in St. Gabriel,

24 They learn to set up video product of their activities during the program, see, for example, https://www.youtube.com/watch?v=IUVGNkKGi6M as well as https://www.facebook.com/ youthpilgrimagesupporting their activities.
Austria, in 2000. ${ }^{25}$ Starting in 2008, the forum shifted its focus to youth, and is now attended by around 45 young people from some 17 predominantly Christian and Islamic countries on the five continents. It combines class lectures, tutorials, and visits to religious sites. In addition, the participants have the opportunity to cook their traditional meals from their respective countries and to perform at a cultural night.

Indonesian youth have participated since the second VICISU in 2010. From my observation as one of the lecturers at the program, they have been able to bring insights to the class discussions with questions and examples based on religious relations in Indonesia. The lectures and tutorials, which not only focus on the theological aspect of inter-religious relations but also pay careful attention to the legal, cultural, philosophical, social, and political aspects of religion have provided ample opportunities to the participants to be more open minded in their understanding of and interactions with the "religious other." A discussion on the place of Christians and Jews from the Islamic perspective, for example, created a heated discussion among Muslim participants from various countries, and it was interesting to

25 See, http://www.univie.ac.at/vicisu/history/the1st-vienna-international-christian-islamic-summeruniversity-vicisu-2008/. The VICISU has been financially supported by The Austrian Federal Ministry of Sciences and Research, Austrian Ministry of Foreign Affairs, and the University of Vienna. The contributions of Prof. Ingeborg Gabriel and Prof. Irmgard Marboe are vital to the continuation of this program. 
witness how the Indonesian Muslim participants offered an inclusive way in their understanding of the issue. In 2018, the committee added one new course on conflict management and communication taught by the European Peace University in Schlaining, Austria.

In addition, daily interactions at the monastery where the Indonesian participants, who were mostly Muslim, lived and interacted with other participants as well as with the Fathers gave them a meaningful experience. It would have been hard for a Muslim who was not an open-minded person to live in a monastery and hear the church bells at least three times a day for three weeks. This, as stated by most Indonesian participants from 2010 , 2012, 2014, 2016, and 2018 batches, has been a life experience that has changed the way they see the "other."

The Indonesian youth who participated in VICISU have contributed significantly in sharing Indonesian Islam, which is characterized by moderate and inclusive perspectives. They are also very active in social media networks with fellow alumni, chiefly through Facebook and Instagram. Through these media they share information on various programs and actions related to inter-religious dialogue in their respective countries.

\section{Concluding Remarks}

As the above examples suggest, the initiatives in conducting programs as well as follow-up activities and forums as a way in expressing religiosity came from various parts of the academic world: students (YIPC Indonesia, VICISU), university programs (Youth Interfaith Gathering, Concert for Harmony, and Advocacy for Pluralism, VICISU), and universities and alumni (IYP). The question is: Could we categorize these programs and activities as youth activism? Are there sufficient emphases on "direct vigorous action"?

If we borrow the "Seven Moments of Inter-religious Dialogue" approach proposed by J.B. Banawiratma, we could conclude that those programs and activities conducted by and involving Indonesian youth have to some extent touched the seven moments/levels he has proposed, namely: Dialogue of Life, Social Analysis and Ethical Reflection, Understanding One's Own Faith, Inter-religious Dialogue: Sharing Faith through Experiences, Theological Dialogue: Inter-textual Reading, Dialogue of Action, and Intra-religious Dialogue. $^{26}$

The dialogue that takes place in the daily lives of small communities is called "dialogue of life." Here community members, male and female, from different religious backgrounds meet each other and are primarily concerned with their daily needs, such as health, education, and housing. Even though the programs mentioned

26 J.B. Banawiratma, "Apa itu Dialogue?" in Banawiratma and Bagir, p. 8. 
above are deliberately planned and thus somehow a little utopian, it is possible to say that YIFoS community conducted a dialogue of life as they were concerned with issues related to health and marginalized communities. In addition, the Youth Interfaith Gathering on Religion and Disaster had also reflected this dialogue of life as participants tried to understand problems related to natural disaster in Yogyakarta.

The second moment of dialogue is related to ethical choices. Communities of different faiths decide on which values to uphold. These values include peace, gender equity, human rights, and environmental awareness. This type of dialogue could be seen in YIFoS community. Their decision to deal with difficult questions related to religion and sexuality and to speak courageously about the rights of people with non-normative sexual orientations shows a clear ethical choice. A similar effort to advocate for peace has been made by the Pluralism Knowledge Program, Young Interfaith Peacemaker Community Indonesia, and Interfaith Youth Pilgrimage community.

The third moment of dialogue happens when the members of the community of different faiths and religious backgrounds try to reflect on their own faith. This is very important as their ethical choice can be based on and strengthened by their faith. And this third moment is closely related to the fourth moment of dialogue in which they share their faith and religious experience. If we look at all the above-mentioned programs, almost all set aside time when the youth as participants reflected and shared their own faith and religious experiences in small groups formats. It was through this kind of practices that they were able to avoid being manipulative or aggressive and to learn from other faith traditions.

The fifth moment of dialogue takes place where theologians and other specialists share their knowledge and experience at academic level. They communicate their religious traditions and learned from others. Issues that might create prejudice, such as religious proselytization, need to be discussed. The Vienna International ChristianIslamic Summer University is an example. Even though the participants were youth and many of them were not theologians, they did spend a lot of time discussing theology and issues that might cause prejudice and hatred among Muslims and Christians.

The sixth moment is dialogue of action. It is realized that a sustainable inter-religious harmony has to be coupled with communal action to transform socio political life. Examples of this dialogue are found in YIFoS, Youth Interfaith Gathering Event, Concert for Harmony, Advocacy for Pluralism, Young Interfaith Peacemaker Community Indonesia, Youth Interfaith 
Pilgrimage, and VICISU. Those youth involved in the programs were and are concerned with action for a better and peaceful life.

The seventh moment is intrareligious dialogue where members of the community of different faiths and religious backgrounds conduct selfcriticism in relation to their own faiths. Their meetings with people of other faiths and religions backgrounds will deepen their own faith. This, I believe, is the expectation from the organizers of all the above-mentioned programs and had to some extent been experienced by the participants.

Even though the above-mentioned programs reflect the seven moments of dialogue proposed by J.B. Banawiratma, I think one area that needs to be strengthened is transforming youth's participation and contribution to interfaith dialogue into activism. This can be achieved through developing networks between universities, with CSOs especially those concerned with interfaith dialogue issues, and, when possible, with the government, especially the Ministry of Religious Affairs and the Ministry of Foreign Affairs and its Directorate of Public Diplomacy.

\section{Acknowledgments:}

I would to express thanks for the excellent help of Dr. Gregory Vanderbilt for reading the first draft of this paper. I also want to thank my student Subhani Kusuma Dewi for helping me with data collection.[]

\section{References}

Ali, Mukti. "Dialogue between Muslims and Christians in Indonesia and Its Problems," paper presented at World Council of Churches, Lebanon, 1970.

Banawiratma, J.B., Zainal Abidin Bagir, et.al. Dialog antarumat Beragama: Gagasan dan Praktik di Indonesia. Bandung: Mizan, 2010.

Boland, B.J. The Struggle of Islam in Modern Indonesia. The Hague: Martinus Nijhoff, 1982.

Hammer, Stefan and Fatimah Husein, eds. Religious Pluralism and Religious Freedom: Religions, Society and the State in Dialogue. CRCS UGM and the Department of Legal Philosophy, Law of Religions and Culture of the University of Vienna, Austria, 2013.

Hasan, Noorhaidi. "Violent Activism, Islamist Ideology, and the Conquest of Public Space among Youth in Indonesia." In Kathryn Robinson, ed. Youth Identities and Social Transformations in Modern Indonesia. Leiden: Brill, 2016.

Hiariej, Eric. "Aksi dan Identitas Kolektif Gerakan Islam Radikal di Indonesia.” In Jurnal Ilmu Sosial dan Ilmu Politik, Vol. 14, No. 2 (2010): 131-168.

Khanis, Suvianita. "Human Rights and the LGBTI Movement in Indonesia." Asian Journal of Women's Studies, 19: 1 (2013): 127-138.

Ridwan, Rinaldi and Joyce Wu. "Being Young and LGBT, What could be Worse? Analysis 
of Youth LGBT Activism in Indonesia: Challenges and Ways Forward." Gender and Development, 26: 1 (2018): 121-138.

Sumartana,Th. "Sejarah Singkat, Visi dan Misi Institut DIAN/Interfidei. Interfidei Newsletter, Special Edition 2001.

Sunardi, St. "The Dead End of Religious Dialogue in Indonesia.” Interface, No.4 (May 2001): 55-67.

Online Resources:

www.anglican-communion.org and www.lambethconference.org

www.wmc.org.sa and themwl.org

http://www.religionsforpeace.org/vision-history/history

http://wcc-coe.org/wcc/what/interreligious/cd48-10.html

https://yifos.wordpress.com/

www.worldinterfaithharmonyweek.com

www.un.org/en/events/interfaithharmonyweek

http://ugm.ac.id/en/news/6058-interfaith.joint.humanitarian.activities.should.be.encouraged

http://ugm.ac.id/en/news/6182-interfaith.students.in.yogyakarta.open.religious.and.disaster. dialogue

http:/ugm.ac.id/en/news/6228-crcs.holds.concert.of.harmony.youth.religion.and.peace

http://www.theharmonyintl.com/44-uncategorised/85-world-interfaith-harmony-week-events. html

http://crcs.ugm.ac.id/pluralism/profile

http://crcs.ugm.ac.id/pluralism/pluralism-advocacy/information/5/ESSAYS-REFLECTINGON-ADVOCACY.html

http://younginterfaithpeacemaker.org/

http://worldinterfaithharmonyweek.com/event-report-2/?report=972

http://icrs.ugm.ac.id/video-gallery/detail/21/interfaith-youth-pilgrimage.html

lifestyle.kompasiana.com/catatan/2013/11/14/catatan-perjalanan-interfaith-youth-pilgrimage1-609349.html

https://www.youtube.com/watch?v=1UVGNkKGi6M

https://www.facebook.com/youthpilgrimagesupporting their activities

http://www.univie.ac.at/vicisu/history/the-1st-vienna-international-christian-islamic-summeruniversity-vicisu-2008/ 